\title{
Review
}

\section{Restitution and the politics of repair: Tropes, imaginaries, theories}

\author{
Magdalena Zolkos \\ Edinburgh University Press, Edinburgh, 2020, pp. 160, \\ ISBN: 978147445309
}

Contemporary Political Theory (2022) 21, S126-S129. https://doi.org/10.1057/s41296021-00508-7; published online 26 July 2021

The protests that erupted across the USA and abroad in the wake of George Floyd's murder by Minneapolis police officer Derek Chauvin, with their calls to defund the police, popularized the decades-long work of prison abolitionists. At the heart of this movement is a question about whether political institutions that have been the source of harm can be repaired. If the passage of the 1964 Civil Rights legislation was a source of hope for the possibilities of genuine progress to address social and political inequality, the years since have been cause for receding optimism. During this period of backlash, the carceral-industrial complex grew to unprecedented levels. Today the US incarcerates a greater percentage of its population per capita than any other country, with Black prisoners overrepresented among those jailed and detained by police. Judging whether prisons and police can be repaired to better serve communities, or whether they are not broken but working as the anti-Black institutions they were intended to be, guides the work of primarily Black activists and scholars who are wrestling to define abolition today, especially in terms of the movement's strategies and goals.

Not unconnected to doubts about US democracy raised by the racial inequalities of mass incarceration, repair is also a key term in a strand of recent democratic theory that has emerged to bear witness and express grief over the erosion of both democratic norms and institutions, and also democracy as an aspirational ideal (e.g., Honig, 2017). A large impulse of this theoretical writing is to think through where and how to repair those institutions, norms, and attachments. Underspecified in both literatures is what is meant by repair. Does repair mean restoring back to an original condition or putting back into good working order? Abolitionists rightfully reject repair and reform on these grounds. Or is repair a process of rebuilding that is transformational, resulting in something new?

Magdalena Zolkos' Restitution and the Politics of Repair: Tropes, Imaginaries, Theories arrives in the midst of these debates to offer a historical and theoretical exegesis on the origins of repair and its political implications. Though the

(C) 2021 The Author(s), under exclusive licence to Springer Nature Limited. 1470-8914 Contemporary Political Theory Vol. 21, S3, S126-S129

www.palgrave.com/journals 
restitution of objects taken during the colonial period and now residing in the collections of western museums, together with the extra-legal obligations of states and individuals, are the starting points for Zolkos' inquiry, her analysis centers the motivations underlying the demand for repair. Specifically, she investigates what imaginative work repair does for those who seek it. She argues that repair links objects and subjects, and how subjects think of repair; and also that what needs repair says as much about what subjects believe needs correction as it does about the subjects themselves and who they are. Repair, according to Zolkos, is retrospective and forward-looking, because how people understand the past, and their relationship to it, informs who they wish to become.

What Zolkos calls the grammar of restitution-whether or not repair takes a direct object-shapes its politics. A transitive construction of the verb 'to restitute' expresses a relationship between a subject and an object from which a subject has been separated or dispossessed. This grammatical construction upholds a clear distinction between persons and things, in addition to undergirding a system of private ownership. It represents the dominant tradition of restitution in European political thought, while the intransitive construction, in which there is no direct object and the subject returns to a prior condition, has been less developed. Zolkos traces repair back to four restitutive scenes, beginning with Grotius' writings on restitution of property and return of prisoners in the context of war and conflict, through Mary Shelley's Frankenstein, Émile Durkheim's theories, and Melanie Klein's psychoanalytic work on reparation. In this tradition, restitution is linked to prelapsarian tropes of return to the era before the violence and the harm it caused. Repair is about undoing wrongs as part of reparative or curative process. It can span the fantasy of wiping away, not just the painful consequences of an event as well as, in some cases, the event itself, as if it never happened, thus effectively annulling the past to produce a protective, if untruthful, counterfactual history. I will briefly review how this operates in the second, third, and fourth scenes Zolkos examines.

The story of Frankenstein's Creature illuminates the limits of repair in its transitive construction. The Creature is not human, even if his body is an assemblage of human parts taken from deceased persons. The Creature's suffering cannot be addressed because he is seen as an object rather than a fellow human being. He does not merit the 'universal benevolence' that motivates calls for repair in contemporary humanitarianism. Zolkos argues that the denial of this shared identification elucidates 'the concealed exclusionary logic upon which the discourse of universal humanity is based' (p. 45). For Frankenstein, repair means killing his Creature, effectively 'undoing' the act that brought him to life, which itself represented the wrongful 'undoing' of death. Because restitution turns out to be reserved only for those who are considered human, Zolkos' analysis of Frankenstein's Creature indirectly helps to explain why some Afro-pessimists reject reparations. They seem to intuit what Zolkos makes evident, which is that restitution, or the promise of reparations, extends only to the boundary of those who

(c) 2021 The Author(s), under exclusive licence to Springer Nature Limited. 1470-8914 Contemporary S127 Political Theory Vol. 21, S3, S126-S129 
have been considered fully human and, therefore, cannot be the means of extending this status to Black Americans who have been treated as non-humans.

In Durkheim's work, Zolkos identifies a second kind of 'undoing', but one that breaks down the division between object and subject. Durkheim observed the rise of restitutive laws across Europe as a response to the growing social isolation and dislocation caused by industrialization. These laws, according to Durkheim, produced the idea of an 'organic social body' among subjects who, unmoored from their traditional communities and attachments, had stronger understandings of themselves as individuals. Zolkos argues that the concept of restitution also generates, for Durkheim, a much-needed theory of shared identity and solidarity among people experiencing geographic and psychic dislocation that repressive laws, focused on crime and punishment, had supplied in the past (p. 64). As she explains, Durkheim theorized that the legal power of restitutive laws to make the past 'un-happen' rested on 'the image of society as an organic body' - a living unit of differentiated and interdependent parts-to which norm violation causes a malfunctioning or an ailment. For that reason, by reinstating the status quo ante, 'restitutive law cures the wounded social body' (p. 68). Here repair is expressed by turning back the clock. Zolkos sees 'moral individualism', which Durkheim considered a quasi-religious, abstract commitment to the sacredness of individual human life and dignity, as something that, in Durkheim's later writings, counters the effects of social alienation and atomized individualism (p. 72). Put differently, repair becomes a way of reconceptualizing both subject and object as well as the relations among subjects and objects and between them.

The idea of undoing the past, or the fantasy of that action, is predominant in Sigmund Freud's study of Rat Man. Zolkos rejects the politics of such fictions in favor of Klein's theory of reparative action as a way of addressing traumatic loss. In particular, Zolkos appreciates Klein's attention to ambivalence: how, for Klein, the impulse to repair is bound up with a desire to also destroy the beloved object. Psychoanalysis, because it acknowledges the role of unconscious desire in explaining our actions and motivations, is attractive to Zolkos, because it captures the contradictions and fantasies bound up in the call for repair. Moreover, psychoanalysis makes clear how the subject's desire is linked to the desired object. In the case of repair, psychoanalysis helps explain how it is possible that benevolence can spring from genuine sympathy and also be weaponized. Klein's grasp of ambivalence sheds light on how reparations for slavery can be invoked defensively, not as a way of addressing past wrongs that include acknowledgment, but as cheap concessions that preserve the status quo for white Americans and make the past un-happen.

For me, this is where the value of Zolkos' scholarship really shines, but it is also the place where I wish she had done more to elaborate the political stakes of her research. This is a richly detailed and closely argued text on the conceptual tropes and imaginaries at work in our calls for repair and restitution. It is an incredible 
resource for those needing to think through questions such as What needs to be repaired? Why does it need to be repaired? Why do we think it needs repair? And who is the 'we' that is being proclaimed as collective subject?

\section{Reference}

Honig, B. (2017) Public Things: Democracy in Disrepair. New York: Fordham University Press.

Publisher's Note Springer Nature remains neutral with regard to jurisdictional claims in published maps and institutional affiliations.

Ali Aslam

Mount Holyoke College, South Hadley, MA 01075, USA aaslam@mtholyoke.edu 